\title{
Distribution and Diversity of Macrobenthos in Sangu River, Bangladesh
}

\author{
Md. Mozammal Haque ${ }^{1}$, Abu Sayed Muhammad Sharif ${ }^{2}$, Md. Kawser Ahmed ${ }^{1,3}$, Ferdows Anwar , $^{4}$ \\ Seema Rani ${ }^{3}$, Md. Habibur Rahman Molla ${ }^{5}$ and Makidul Islam Khan ${ }^{3}$ \\ ${ }^{1}$ Department of Oceanography, University of Dhaka, Dhaka 1000, Bangladesh \\ ${ }^{2}$ Bangladesh Oceanographic Research Institute, Cox's Bazar, Bangladesh \\ ${ }^{3}$ International Centre for Ocean Governance, Faculty of Earth and Environmental Sciences, University of Dhaka, Dhaka 1000, Bangladesh \\ ${ }^{4}$ Department of Environment, Ministry of Environment, Forests and Climate Change, Dhaka1207, Bangladesh \\ ${ }^{5}$ Department of Biology, Faculty of Science, King Abdulaziz University, Jeddah 21589, Kingdom of Saudi Arabia
}

Manuscript received: 05 January 2021; accepted for publication: 27 April 2021

\begin{abstract}
This study was conducted to understand the macrobenthos distribution and abundance in Sangu River to monitor the aquatic pollution level. Both surface and sub-surface water and benthic sediments were collected from three stations of the Sangu River. A few indices viz. Shannon-wiener, Simpson, Margalef's and Evenness were used to estimate the macrobenthic assemblages. In this study, a total of 11 major taxa comprising total 870 macobenthic species were identified. Shannon-wiener index was maximum (1.58) at lower part (LP) which indicated moderate to heavily pollute aquatic environment of the Sangu River. The average diversity values of Shannon, Evenness, Simpson and Margalef's indices were $0.97,0.43,0.39$ and 1.54 respectively. The concentration of dissolved oxygen was the lowest $(4.90 \mathrm{mg} / \mathrm{L})$ at $\mathrm{LP}$ and the highest $(5.08 \mathrm{mg} / \mathrm{L})$ at upper part (UP). This study showed that macrobenthos abundances was influenced by higher temperature, salinity, and $\mathrm{pH}$. The percentage of organic carbon content was maximum $(98.18 \%)$ at LP where the macrobenthic abundance was 330 individuals $/ \mathrm{m}^{2}$, whereas it was minimum $(80.77 \%)$ at UP where macrobenthic abundance was 248 individuals $/ \mathrm{m}^{2}$ that indicated carbon content also influence the assemblages of the macrobenthos in the Sangu River. A clear gradient of physico-chemical and benthic soil parameters fluctuation was also found to be responsible for the variations of macrobenthos assemblage in the Sangu River.
\end{abstract}

Keywords: Macrobenthos, Distribution, Diversity, Soil and water quality parameters, Sangu River

\section{INTRODUCTION}

Macrobenthos are organisms that are living on or inside the bottom of a water body (Barnes and Hughes, 1999; Idowu and Ugwumba, 2005; Khan et al., 2007). Generally, macrobenthos link with the primary producers and play an important role in the circulation and recirculation of nutrients throughout the aquatic ecosystems (Ikomi et al., 2005). The distribution and diversity pattern of macrobenthic communities is totally controlled by the environmental and biological factors like habitats type, water and sediment quality, food supply, dissolve oxygen, substrate composition, sedimentation rates and the bathymetry features (Olenin, 1997; Coleman et al., 2007; Gogina and Zettler, 2010). The spatial and temporal distribution of macrobenthos is remarkably exaggerated due to the changes of water depth, temperature, salinity, pressure, current, density, organic matters content,

Corresponding author: Mozammal Haque

Email: mozammal006@gmail.com

DOI: https://doi.org/10.3329/dujees.v9i2.55087 siltation, toxicity and sedimentation processes (Pearson, 1975).

The Sangu River, a transboundary river, originates in the Arakan Hills of Myanmar and enters Bangladesh near Remarki of Thanchi upazilla of Bandarban district. It is a shallow river but becomes more brutal during rainy season. Sometimes, it develops rapid currents. It falls to the Bay of Bengal through Chattogram. It is one of the most substantial rivers that offers support for fish and shellfish's spawning, nursing and feeding ground. Sangu gas field is located about $50 \mathrm{~km}$ at the south west of Chattogram. The ecosystem of the river might have been influenced by the anthropogenic activities such as the Sangu gas field and the confluence of the nearby mighty Karnafully River. Since the distribution and abundance of fish and shellfish species are changed temporally and spatially, it is very important to understand the aquatic ecosystem of the Sangu River. In this case, studies on macrobenthos distribution and assemblage might help to understand the condition of the river for better management. Globally macrobenthos are the most universally used 
Haque et al.

organisms for biomonitoring in riverine habitat (Bonada et al., 2006).

A few studies for example Sarker et al. (2016), Sharif et al. (2017) and Islam et al. (2013) focused on macrobenthic community structure in the Meghna river estuary at Chairmanghat, Noakhali and the Bakkhali river estuary at Cox's Bazar, lower Meghna river estuary and Karnaphuli river respectively. Prianka et al. (2020) assessed the shellfish occurrence and distribution in the Sangu River estuary using an estuarine set bag net. However, there is scarce study on the macrobenthos distribution and abundance of in Sangu River. That is why, this study aims to assess the macrobenthos distribution and abundance in the Sangu River. In addition, this study also assesses the physicochemical parameters of surface waters and bottom sediments of the Sangu River to understand the environmental impacts on the macrobenthos distributions and abundance in the river.

\section{MATERIALS AND METHODS}

\section{Study Area}

The study was directed to the Sangu River in Bangladesh. Three sampling stations were selected for the research- Upper Part (UP), Middle Part (MP) and Lower Part (LP) (Figure 1). Description of the sampling sites were given to the Table 1 .

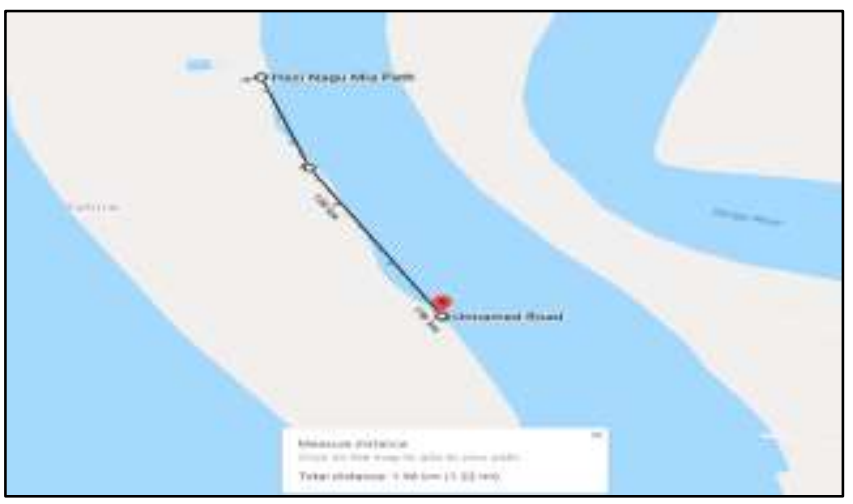

Figure 1. Geographical Locations of the Sampling Stations in Sangu River

Table 1. Description of the Sampling Stations in the Sangu River

\begin{tabular}{lllll}
\hline Name of $\begin{array}{l}\text { of } \\
\text { the }\end{array}$ & $\begin{array}{l}\text { Sampling } \\
\text { River }\end{array}$ & $\begin{array}{l}\text { Description of } \\
\text { Stations }\end{array}$ & GPS Position \\
\cline { 3 - 5 } & & Locations & Latitude & Longitude \\
\hline Sangu & $\mathrm{UP}\left(\mathrm{S}_{1}\right)$ & Waiddhar Hat & $22.142^{\circ} \mathrm{N}$ & $91.841^{\circ} \mathrm{E}$ \\
\hline
\end{tabular}

\begin{tabular}{lllll}
\hline River & MP $\left(\mathrm{S}_{2}\right)$ & Fakir Hat & $22.136^{\circ} \mathrm{N}$ & $91.843^{\circ} \mathrm{E}$ \\
\cline { 2 - 5 } & $\mathrm{LP}\left(\mathrm{S}_{3}\right)$ & South Gahira & $22.126^{\circ} \mathrm{N}$ & $91.849^{\circ} \mathrm{E}$ \\
\hline
\end{tabular}

\section{Materials used in the Field and Laboratory}

In this study, several scientific instruments and chemicals were used to collect, preserve and process the samples. A list is given below:

1. Grab Sampler

2. Thermometer

3. Dissolve Oxygen (DO) Meter

4. Zipper Bag

5. Ross Bengal Powder

6. Sieve Plate and Niddle

7. $10 \%$ Buffer Formalin

8. Slide, Microscope and Motic Camera

\section{Collection of Samples and Preservation}

The benthic samples and sediments were collected from the bottom substrate of each sampling location during October to December 2018 by using an Ekman grab sampler having an opening mouth of $0.95 \mathrm{~m}^{2}$ and water samples collected by $500 \mathrm{ml}$ bottle. The bottles were pre-washed properly each time to remove any form of contaminants. The water samples were preserved temporarily until analysis.

\section{Sample Placement, Analysis and Identification}

The collected samples were placed to the laboratory. All coarse materials were sorted, counted, and identified. The specimens were identified based on the external morphology and categorized into various taxa following the available keys (Belaluzzaman, 1995). The selected physical and chemical parameters were also measured. The physical and some chemical parameters were measured on the spot and the rest were determined in the laboratory.

\section{Data Analysis}

Statistical data were analyzed by using MS Excel (version-13). Diversity and other indices were calculated by using different formulas:

\section{Taxa Richness $(R)$}

The taxa richness of any ecosystem was built on the numbers of taxa found in the area that does not reflect the relative dominance of species. 
Shannon-wiener Index (H) (Shannon, 1948)

The collected data were combined to find the values of Shannon-wiener index that support to determine both number of species and the even distribution of individuals.

Species richness index (d) and evenness index were calculated by using the following equations.

(i)

$$
\mathrm{H}=-\Sigma\left[\left(\mathrm{P}_{\mathrm{i}}\right) * \ln \left(\mathrm{P}_{\mathrm{i}}\right)\right]
$$

and

$\mathrm{E}=\mathrm{H} / \mathrm{H}_{\max }$

Here,

$\mathrm{P}_{\mathrm{i}}=$ Number of individuals of species $\mathrm{i} /$ total number of samples

$\mathrm{S}=$ Number of species or species richness

$\mathrm{H}_{\max }=$ Maximum diversity possible

$\mathrm{E}=$ Eveness $=\mathrm{H} / \mathrm{H}_{\max }$

\section{The Margalef's Index (D) (Margalef, 1958)}

Species Richness (D) is the ratio between the total species (S) and the total numbers of individual $(\mathrm{N})$. It was used to compare one community with another. The index is calculated using the following formula:

$\mathrm{D}=\frac{S-1}{L n N}$

Here,

$\mathrm{D}=$ Margalef's index

$\mathrm{S}=$ Number of species in sample

$\mathrm{Ln}=\log$ normal

$\mathrm{N}=$ Total number of individuals in sample

Evenness (E) (Buzas and Gibson, 1969)

Evenness of taxa was calculated by the following formula:

$\mathrm{E}=\mathrm{H} / \ln (\mathrm{R})$

Here,

$\mathrm{H}=$ Shannon-Wiener index

$\mathrm{R}=$ Species richness

\section{Simpson Index (D) (Simpson, 1949)}

The Simpson Index ranges between 0 and 1, and the greater the value, the greater the sample diversity.
Simpson Index $(\mathrm{D})=\frac{1}{\sum_{i=1}^{S} P i 2}$

Here,

$\mathrm{P}=\mathrm{n} / \mathrm{N}$

$\mathrm{n}=$ individuals of one particular specie

$\mathrm{N}=$ the total number of individuals

$\Sigma=$ the sum of the calculations

$\mathrm{S}=$ the number of species

\section{RESULTS AND DISCUSSION}

\section{Distribution and Diversity of Macrobenthos}

This study identified a total of 870 species under 11 major taxa from three different stations of the Sangu River. The overall percentage of Nemertina was higher than other benthic groups in the Sangu River (Table 2). Nemertina was the most dominant taxa that occupied $48.05 \%$ of the species followed by Oligochaete (22.07\%), Polychaete (16.32\%), Bivalvia shell (3.22\%), Echinodermata (2.99\%), Platyhelminthes (1.84\%), Crustacean (1.38\%), Cumacea (1.26\%), Cyclopoida $(0.92 \%)$ and Calanoida $(0.57 \%)$. However, Polychaete was the most dominated taxa in the Meghna River estuary at Chairmanghat, Noakhali and the Bakkhali River estuary at Cox's Bazar (Sarker et al., 2016). The number of microbenthos organisms (15 species) recorded in the Sangu River by Prianka et al. (2020) was very low because of sampling differences since they used estuarine set bag net to collect the samples.

Table 2. Major Taxa of Macrobenthos in three Stations of the Sangu River

\begin{tabular}{ccccccc}
\hline $\begin{array}{c}\text { Benthos } \\
\text { Groups }\end{array}$ & $\mathrm{S}_{1}$ & $\mathrm{~S}_{2}$ & $\mathrm{~S}_{3}$ & Mean & Total & $\%$ \\
\hline Polychaete & 11 & 14 & 117 & 47.83 & 142 & 16.32 \\
\hline Oligochaete & 34 & 72 & 86 & 64 & 192 & 22.07 \\
\hline Nemertina & 179 & 148 & 91 & 139.33 & 418 & 48.05 \\
\hline Amphipod & - & 7 & 5 & 4 & 12 & 1.38 \\
\hline Bivalvia shell & 13 & 4 & 11 & 9.33 & 28 & 3.22 \\
\hline Calanoida & 1 & - & 4 & 1.67 & 5 & 0.57 \\
\hline Crustacean & 4 & 2 & 6 & 4 & 12 & 1.38 \\
\hline Cumacea & 1 & 10 & - & 3.67 & 11 & 1.26 \\
\hline Cyclopedia & 2 & 3 & 3 & 2.67 & 8 & 0.92 \\
\hline Echinodermata & - & 24 & 2 & 8.67 & 26 & 2.99 \\
\hline Platyhelminthes & 3 & 8 & 5 & 5.33 & 16 & 1.84 \\
\hline Total & 248 & 292 & 330 & 290.5 & 870 & 100 \\
\hline
\end{tabular}

The Percentage and distributions of macrobenthos in each stations of the Sangu River have been documented in Figure 2. In station $S_{1}$ and $S_{2}$, the percentage of Nemertina was 72 and 51 respectively. However, in 
station $\mathrm{S}_{3}$, Polychaete was the most dominated taxa. In general, Nemertina, Oligochaete, Polychaete and Bivalvia shell were the most dominating groups at all the stations of the Sangu River.

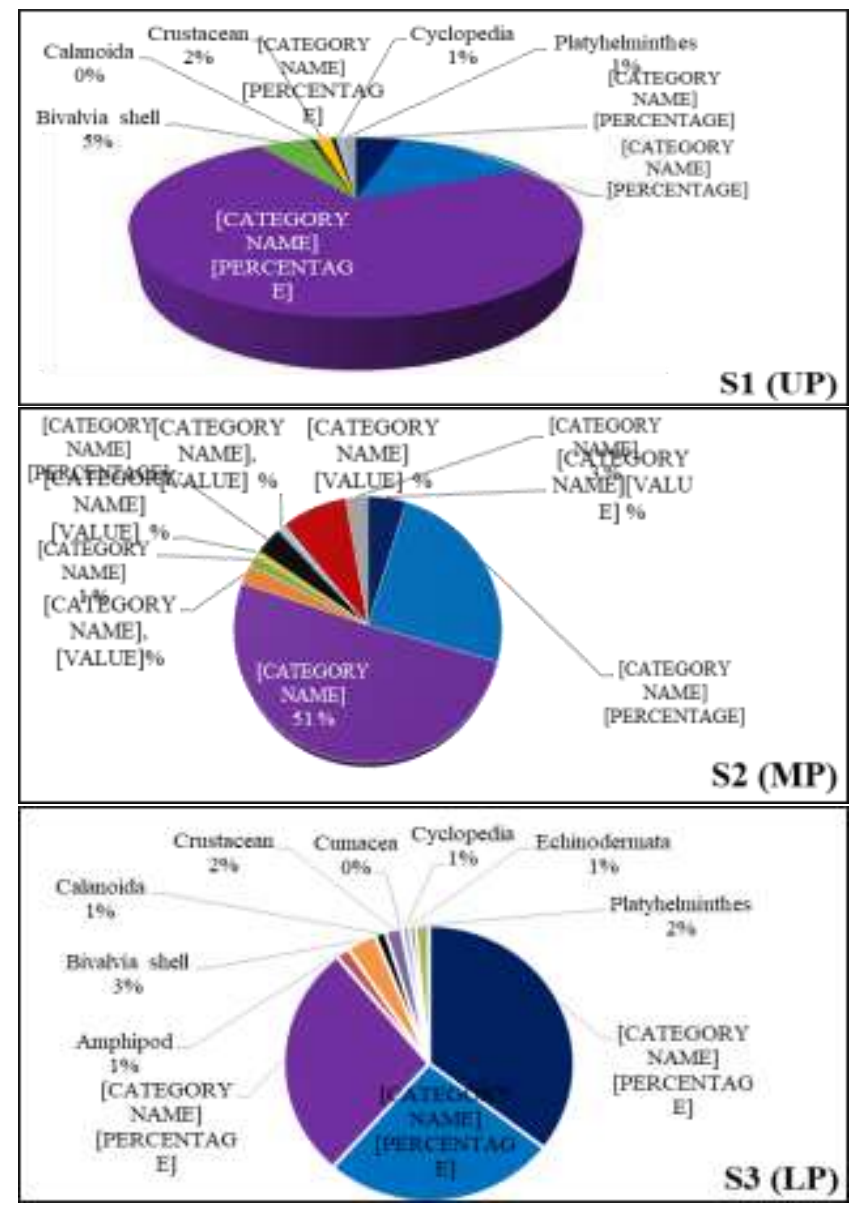

Figure 2. Distributions of Macrobenthos in three Stations (UP, MP, LP) of the Sangu River

Macrobenthic species distribution comparison among the three stations are presented in Figure 3.

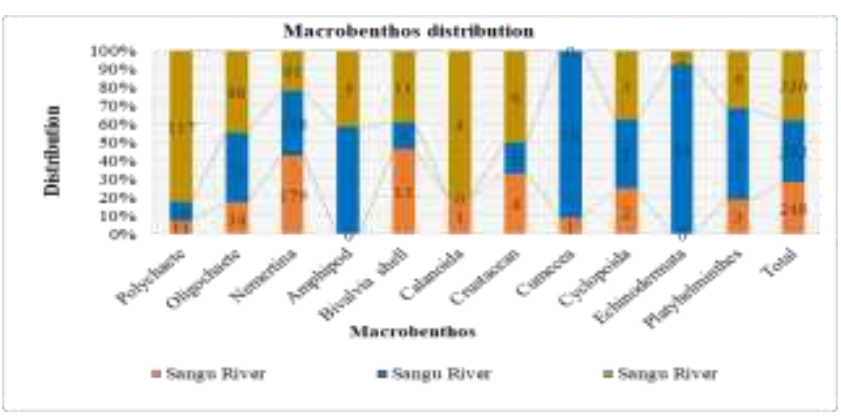

Figure 3. Comparison of Macrobenthic Species Distribution in three Stations of the Sangu River

Different diversity indices showed important differences in the studied area. Simpson values of the sampling stations were identified as the maximum in station $\mathbf{S}_{\mathbf{1}}(0.54)$ and the lowest in station $\mathbf{S}_{\mathbf{3}}(0.27)$ respectively. Shannon-wiener diversity index is used to present the difference in abundance and evenness of species community. Shannon diversity index was maximum at station $\mathbf{S}_{\mathbf{3}}$ (1.58). In biological communities, Shannon-wiener diversity index varies from 0 to 5 . If the values are less than 1 , it characterizes heavily polluted condition of the aquatic environment. But the values in the range of 1 to 2 represented moderate pollution level while the values above 3 showed stable environment (Wilhm and Dorris, 1966). This study showed, the aquatic environment of the Sangu River was moderate to heavily polluted that are in line with Prianka et al. (2020). The average diversity values of Shannon index, Evenness, Simpson index and Margalef's index were $0.97,0.43,0.39$ and 1.54. A comparative macrobenthic species diversity indices of three stations of the Sangu River was given in Table 3.

Table 3. Macrobenthic Diversity Indices of three Stations of the Sangu River

\begin{tabular}{lllll}
\hline Stations & $\mathrm{S}_{1}$ & $\mathrm{~S}_{2}$ & $\mathrm{~S}_{3}$ & Mean \\
\hline Taxa_S & 9 & $* 10$ & $* 10$ & 9.67 \\
\hline Individuals & 248 & 272 & $* 330$ & 283 \\
\hline Simpson D & $* 0.54$ & 0.37 & 0.27 & 0.39 \\
\hline Shannon_H & $\mathrm{ND}$ & 1.38 & $* 1.58$ & 0.97 \\
\hline Evenness & $\mathrm{ND}$ & 0.6 & 0.69 & 0.43 \\
\hline Margalef's & 1.45 & $* 1.61$ & 1.55 & 1.54 \\
\hline *Indicates the highest value among the station.
\end{tabular}

\section{Physico-chemical Parameters of Surface and Sub- surface Water}

The physico-chemical parameters of the surface and sub-surface water of the studied area represented the occurrence, distribution, and diversity of macrobenthos in the Sangu River. The quality of an aquatic ecosystem is mainly dependent on the physico-chemical parameters and these parameters control the biological diversity of any organisms in the aquatic environment. The mean atmospheric and surface temperature, salinity and $\mathrm{pH}$ of Sangu River is shown in Table 4. Overall temperature in three stations of the Sangu River was $30.4^{\circ} \mathrm{C}$. No significant temperature difference was found among the three stations of this study though temperature variations could play an important role in macrobenthic organism's distributions (Ndome et al., 2012). Unanam and Akpan (2006) reported that the distribution of macrobenthos was correlated with the 
temperature. This study reported that higher temperature might influence the abundance of the macrobenthos of the Sangu River and it was found that at higher temperature the abundance of macrobenthos was minimum (Figure 4) that this study supports the findings of Unanam and Akpan (2007). Besides temperature variation, Self and Jumars (1978) reported that soil texture and salinity might also control the distributions of the microbenthic organisms in the coastal and estuarine region. Perkins (1976) also agreed and reported that benthic community structure mostly depends on the environmental factors such as salinity, temperature, DO, organic matter, soil texture and size of sediment particles. Water qualities were also strongly correlated with the distribution and diversity of the macrobenthic communities.

Table 4. Physico-chemical Parameters of three Stations of the Sangu River

\begin{tabular}{llllll}
\hline \multirow{2}{*}{ Site } & Stations & $\begin{array}{l}\text { Surface } \\
\text { Tem. }\left({ }^{\circ} \mathrm{C}\right)\end{array}$ & $\begin{array}{l}\text { Atm. } \\
\text { Tem. }\left({ }^{\circ} \mathrm{C}\right)\end{array}$ & $\begin{array}{l}\text { Salinity } \\
(\mathrm{ppt})\end{array}$ & $\mathrm{pH}$ \\
\hline \multirow{3}{*}{$\begin{array}{l}\text { Sangu } \\
\text { River }\end{array}$} & $\mathrm{S}_{1}$ & 30.8 & 32 & 0.38 & 6.32 \\
\cline { 2 - 6 } & $\mathrm{S}_{2}$ & 30.3 & 31.8 & 0.78 & 6.96 \\
\cline { 2 - 6 } & $\mathrm{S}_{3}$ & 30 & 31 & 8.44 & 7.05 \\
\cline { 2 - 6 } & Mean & 30.37 & 31.60 & 3.20 & 6.78 \\
\hline
\end{tabular}

Variation in salinity plays a great role in the occurrence and distribution of macrobenthos (Pearson, 1975; Pearson and Rosenberg, 1978; Rosenberg, 2001; Ysebaert et al., 2003). This study showed that there was a variation in surface and subsurface water salinity in the sampling stations. Station S3 showed the highest amount of water salinity ( $8.44 \mathrm{ppt})$ in this study which might influence the macrobenthos communities in water body. Kumar and Khan (2013) also reported that there was a significant positive correlation between the salinity and the benthic faunal diversity. Jones (1987) described that Polychaetes, Crustaceans and mollusks mostly interact with the salinity.

Surface water $\mathrm{pH}$ was slightly acidic and correlated with the macrobenthic abundance. This study showed that macrobenthic abundance was maximum at LP (S1) (about 330 individuals $/ \mathrm{m}^{2}$ ) where $\mathrm{pH}$ and salinity was maximum, and surface temperature was minimum (Figure 4).
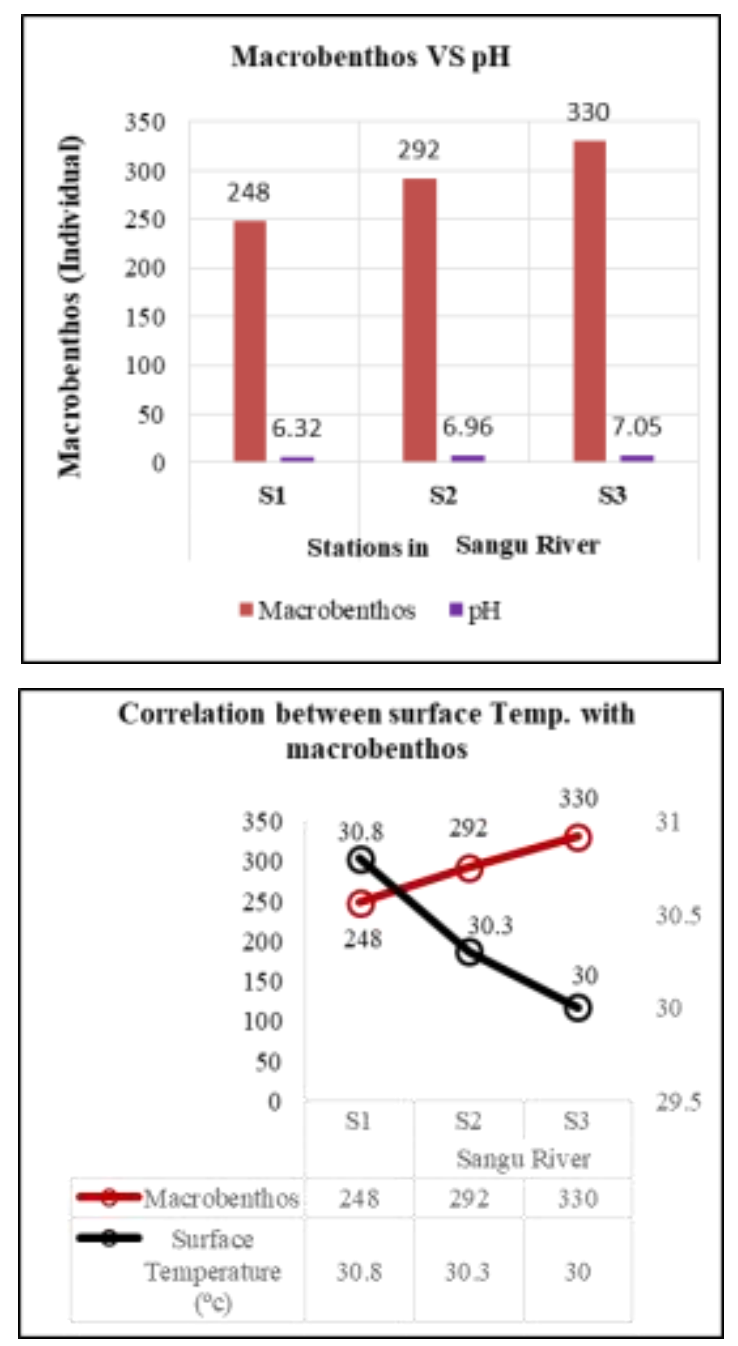

Figure 4. Macrobenthic Relationship with $\mathrm{pH}$ and Surface Temperature of the Sangu River

\section{Physico-chemical Parameters of Bottom Soil}

The concentration of DO was recorded at different depths of the bottom and the lowest concentration of DO was recorded at $\mathbf{L P}(4.90 \mathrm{mg} / \mathrm{L})$ and the highest was at UP (5.08 mg/L) of the Sangu River (Table 5).

Table 5. Physico-chemical Parameters of Bottom Soil of three Stations of the Sangu River

\begin{tabular}{cccc}
\hline \multirow{2}{*}{ Parameters } & \multicolumn{3}{c}{ Stations } \\
\cline { 2 - 4 } & $\mathbf{S}_{\mathbf{1}}(\mathrm{UP})$ & $\mathbf{S}_{\mathbf{2}}(\mathrm{MP})$ & $\mathbf{S}_{\mathbf{3}}(\mathrm{LP})$ \\
\hline Bottom Depth $(\mathrm{m})$ & 0.92 & 1.83 & 1.22 \\
\hline Bottom Temperature $\left({ }^{\circ} \mathrm{C}\right)$ & 29 & 30 & 29.5 \\
\hline DO $(\mathrm{mg} / \mathrm{L})$ & 5.08 & 4.97 & 4.90 \\
\hline Time $(\mathrm{pm})$ & 2.47 & 3.50 & 4.38 \\
\hline Soil Moisture $(\%)$ & 51.85 & 34.04 & 8.33 \\
\hline Organic Carbon $(\mathrm{OC})(\%)$ & 80.77 & 90.32 & 98.18 \\
\hline EC $(\mu \mathrm{S} / \mathrm{cm})$ & 3490 & 2540 & 4090 \\
\hline Soil water $\mathrm{pH}$ & 6.98 & 6.56 & 6.89 \\
\hline Salinity $(\%)$ & 12.6 & 5.96 & 10.7 \\
\hline
\end{tabular}


The soil extruded water $\mathrm{pH}$, moisture and salinity was recorded maximum at the UP. Organic carbon (OC) was maximum at $\mathbf{L P}$ and minimum at UP. The recorded OC was $98.18 \%$ at $\mathbf{L P}$ of Sangu River where the macrobenthic abundance was maximum (330 individuals $/ \mathrm{m}^{2}$ ). However, macrobenthic abundance was minimum (248 individuals $/ \mathrm{m}^{2}$ ) at UP of the Sangu River where the OC value was $80.77 \%$ which indicated that macrobenthos abundance was correlated with higher OC $\left(r^{2}=0.99\right)$ (Figure 5).

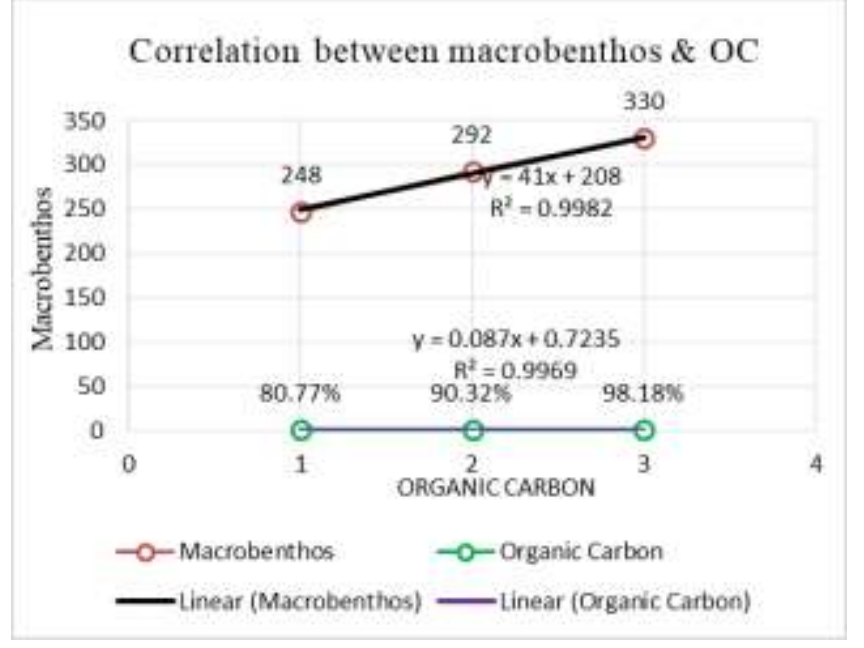

Figure 5. Correlation Between Macrobenthos and Organic Carbon (OC) in the Sangu River

Overall, this study showed that macrobenthos distribution and abundance were influenced by physico-chemical parameters of the water and benthic sediments of the Sangu River. However, aquatic pollution is a great concern for the macrobenthos assemblages in the river. Stakeholders and policy makers should take proper management strategies to conserve the macrobenthos organisms in the rivers. This study suggests monitoring the water quality of any aquatic ecosystem by using the macrobenthos structure as an indicator.

\section{CONCLUSIONS}

Environmental pollution is the major constraints for production of any aquatic area. Any organism can tolerate a certain level of environmental change. However, when there is an abrupt change of surrounding environmental conditions which is beyond the tolerance level, the living organisms are bound to migrate or decrease in that situation. In this study, a total of 11 major taxa including 870 macrobenthic species were identified where
Nemertean, Polychaete, Oligochaeta and Crustacean were the dominated groups at all. Findings of this study reported that the physico-chemical parameters of water and benthic basin are mainly accountable for the variations of macrobenthic communities. Therefore, the present study might be a key upcoming framework to assess the pollution status and the macrobenthic circumstances in the Sangu River that is economically significant. Macrobenthic organism's abundance and distribution of the Sangu River gives an important indication about the health of the river. Based on the sensitivity level, proper management strategies such as reconstruction of the river should be taken to conserve the aquatic ecosystem of the river. This study suggests improving the existing methods of the biological assessment and develop new methods since there is ambiguity about the relationships between the macrobenthic diversity and particular environmental factors.

\section{ACKNOWLEDGMENTS}

The authors would like to thank the Director General of Bangladesh Oceanographic Research Institute (BORI) for permitting them to use Biological Oceanography Lab. Authors also would like to acknowledge Md. Abdullah and Sabiha Khanom Nupa for their help during the sample collection.

\section{REFERENCES}

Barnes, R. S. K., and Hughes, R. N. (1999). An introduction to marine ecology. $3^{\text {rd }}$ edition, Blackwell Science Ltd. pp. 304.

Belaluzzaman, A. M. (1995). Ecology of the Intertidal Macro Benthic Fauna in Cox's Bazar Coastal Area. MSc Thesis, Institute of Marine Sciences, University of Chittagong, Bangladesh.

Bonada, N., Prat, N., Resh, V. H., and Statzner, B. (2006). Developments in aquatic insect biomonitoring: a comparative analysis of recent approaches. Annu. Rev. Entomol., 51, 495-523.

Buzas, M. A., and Gibson, T. G. (1969). Species diversity: benthonic foraminifera in western North Atlantic. Science, 163(3862), 72-75.

Coleman, N., Cuff, W., Moverley, J., Gason, A. S., and Heislers, S. (2007). Depth, sediment type, biogeography and high species richness in shallowwater benthos. Marine and Freshwater Research, 58(3), 293-305.

Gogina, M., and Zettler, M. L. (2010). Diversity and distribution of benthic macrofauna in the Baltic Sea: Data inventory and its use for species distribution 
modelling and prediction. Journal of Sea Research, 64(3), 313-321.

Idowu, E. O., and Ugwumba, A. A. A. (2005). Physical, chemical and benthic faunal characteristics of a Southern Nigeria Reservoir. The Zoologist, 3: 15-25.

Ikomi, R. B., Arimoro, F. O., and Odihirin, O. K. (2005). Composition, distribution and abundance of macroinvertebrates of the upper reaches of River Ethiope, Delta State, Nigeria. The Zoologist, 3: 68-81.

Islam, M. S., Sikder, M. N. A., Al-Imran, M., Hossain, M. B., Mallick, D., and Morshed, M. M. (2013). Intertidal macrobenthic fauna of the Karnafuli estuary: relations with environmental variables. World Applied Sciences Journal, 21(9): 1366-1373.

Jones, A. R. (1987). Temporal patterns in the macrobenthic communities of the Hawkesbury estuary, New South Wales. Marine and Freshwater Research, 38(5): 607-624.

Khan, A. N., Kamal, D., Mahmud, M. M., Rahman, M. A., and Hossain, M. A. (2007). Diversity, distribution and abundance of benthos in Mouri River, Khulna, Bangladesh. International Journal of Sustainable Crop Production, 2(5): 19-23.

Kumar, P. S., and Khan, A. B. (2013). The distribution and diversity of benthic macroinvertebrate fauna in Pondicherry mangroves, India. Aquatic biosystems, 9(1): $1-18$

Margalef, D. R. (1958). Information theory in ecology. General Systems, 3: 36-71.

Ndome, C. B., Udo, I. U., Akpan, I. I., and Udom, C. (2012). Effect of water quality and bottom soil properties on the diversity and abundance of macrobenthic fauna in some tropical grow-out earthen fish ponds. Ecologia, 2(1): 12-22.

Olenin, S. (1997). Benthic zonation of the Eastern Gotland Basin, Baltic Sea. Netherland Journal of Aquatic Ecology, 30(4): 265-282.

Pearson, T. H. (1975). The benthic ecology of Loch Linnhe and Loch Eil, a sea-loch system on the west coast of Scotland. IV. Changes in the benthic fauna attributable to organic enrichment. Journal of Experimental Marine Biology and Ecology, 20(1): 1-41.

Pearson, T. H., and Rosenberg, R. (1978). Macrobenthos secession in relation to organic enrichment and pollution of the marine environment. Oceanography and Marine Biology Annual Review, 16: 229-237.
Perkins, E. J. (1976). The biology of estuaries and coastal waters. Academic Press, London and New York. pp. 678.

Prianka, B., Shamsuzzaman, M. M., Mitu, S. J., and Ahamed, S. (2020). Temporal Variations of Micro Benthic Assemblage in the Sangu River Estuary, Bangladesh. International Journal of Marine Science, 10(7): 1-14.

Rosenberg, R. (2001). Marine benthic faunal successional stages and related sedimentary activity. Scientia Marina, 65(S2): 107-119.

Sarker, M. J., Patwary. M. S. A., Uddin, A. M. M. B., Hasan, M. M., Tanmay, M. H., Kanungo, I., and Parvej, M. R. (2016). Macrobenthic community structure-an approach to assess coastal water pollution in Bangladesh. Fisheries and Aquaculture Journal, 7(1): 157.

Self, R. F. L., and Jumars, P. A. (1978). New resource axes for deposit feeders. Journal of Marine Research, 36(64): 627-641.

Shannon, C. E. (1948). A mathematical theory of communication. The Bell System Technical Journal, 27(3), 379-423.

Sharif, A. S. M., Islam, S., and Islam, M. (2017). Occurrence and distribution of macrobenthos in relation to physico-chemical parameters in the lower Meghna River estuary, Bangladesh. International Journal of Marine Science, 7(12): 102-113.

Simpson, E. H. (1949). Measurement of diversity. Nature, 163(4148): 688.

Unanam, A. E., and Akpan, A. W. (2007). Analysis of physicochemical characteristics of some freshwater bodies in Essien Udim Local Government area of Akwa Ibom State, Nigeria. Proceedings of the 21st Annual Conference of the Fisheries Society of Nigeria, November 13-17, 2006, Calabar. pp. 310-312.

Wilhm, J. L., and Dorris, T. C. (1966). Species diversity of benthic macroinvertebrates in a stream receiving domestic and oil refinery effluents. American Midland Naturalist, 427-449

Ysebaert, T., Herman, P. M. J., Meire, P., Craeymeersch, J., Verbeek, H., and Heip, C. H. R. (2003). Large-scale spatial patterns in estuaries: estuarine macrobenthic communities in the Schelde estuary, NW Europe. Estuarine, coastal and shelf Science, 57(1-2): 335-355. 
